\title{
Planning and Integration of Technologies for Effective Implementation of Blended Learning in Universities in Rivers State, Nigeria
}

\author{
Dr. P. C. Ukaigwe \\ Department of Educational Management and Planning, \\ Faculty of Education, University of Port Harcourt, Rivers State, Nigeria. \\ Innocent U. Igbozuruike \\ Department of Educational Management and Planning, \\ Faculty of Education, University of Port Harcourt, Rivers State, Nigeria.
}

\begin{abstract}
The study investigated planning the integration of technologies in higher institutions as a strategy for effective implementation of blended learning in universities in Rivers State. The design used was descriptive. The population of this study consisted of the 4,377 teaching staff in the three (3) public universities in Rivers State, comprising 2,348 male and 2,029 female teaching staff. The universities are the University of Port Harcourt, Rivers State University and Ignatius Ajuru University of Education. The sample of this study was 590 elements, comprising 327 male and 263 female teaching staff that were drawn from the population using stratified random sampling technique. Instrument of data collection was a questionnaire that yielded a reliability index of 0.84, using test-retest and Pearson Product Moment Correlation techniques. The data generated were analysed using mean to answer research questions. z-test was used to test hypotheses at 0.05 significance level. Findings showed that aligning university's visions with the aspirations of full integration of blended learning into university system, provision of required communication networking infrastructures and modifying curriculum designs to become deliverable through blended learning mode are key ways of integrating blended learning in the university system. Recommendations made included that university managers should consider seriously, the advantages of blended learning in the school system, with a view to using planning to foster the integration of the learning innovation into the traditional face-to-face teaching and learning approach for improving students learning experiences and achievements.
\end{abstract}

Keywords: Planning, Integration, Technologies, Blended Learning, Universities.

\section{INTRODUCTION}

The need for enhancing teaching and learning experiences of students has remained a leading agenda in policy decision-making concerning how to improve curriculum implementation strategies for quality and sustainable higher education. In addressing this, scholars and educationalists have keyed into engagement theory of Greg and Ben to advocate for diversification of learning approaches and the need for teachers to adopt activity-based learning methodologies in teaching-learning settings giving their superiorities to the traditional face-to-face teacher-centred lecture method. This is in keeping with the fact that teaching and learning are so related that they can be likened to a coin that has two sides; it is thus difficult to discuss each side without citing the other. The difference between them is essentially that while the instructor does the teaching, the learner does the learning (Obasi, Obih \& Udosen, 2016). 
Anusiem (2006) observed that learning ensues from observation to exercise, adaptation of skills and alteration of attitudes resulting in change of behaviour. This implied that learning goes beyond observation and listening; it embraces physical activities in which the learners engage their cognitive faculties in manipulation of objects to discover facts and ideas with which to construct and consolidate knowledge. This view agrees with the suppositions of Vygosky's constructivism and Piaget's cognitivitism theses on human learning mechanics, in which the scholars postulated that individuals construct meaning from objects, activities and experiences around their environment (Dele, 2008). Environments in this context is not limited to external conditions of learners' environs, because internal environments of the learners such as psychosocial and subconscious constructs determine to a great extent, how individuals reflects on their experiences, held beliefs and opinions, which in turn governs how they reconcile new experiences with previous ones in order that new knowledge may be constructed. Keeping this perspective, teachers are thus considered as facilitators of knowledge construction, which is in contrast to the conventional lecture method in which lecturers are regarded as repositories and dispensers of knowledge.

Although lecture is traditionally the most used teaching method in higher institutions of learning, in which face-to-face interaction between the lecturer and students are the major features. The lecture method requires students to seat and listen passively, write down major points mentioned by the lecturer, make little or no input in the course of lectures, and hope to remember and regurgitate the facts during examinations. Surely, this method hardly create atmosphere that engages students in learning activities that accelerate the development of psychomotor and cognitive abilities that university education typifies. It is therefore of no surprise that many universities have taken initiatives to augment the traditional lecture method with technologies in order to enrich learning experiences of students and improve their learning outcomes. To put it another way, the advent of Information Communication Technologies (ICTs) have widened ways through which teaching and learning can be conducted without limitations. It has not only made it possible for educators to administer instructions to distance students, because it has further strengthened the need for educators to combine different learning methods and approaches to achieve their instructional objectives. Some of the ICTs-driven innovations in education include e-learning, e-education, distancelearning, and e-professionalism, in addition to blended learning, which is the integration of technologies in instructional processes for the purpose of enriching teaching and learning experiences of both the instructor and the learners (Mezieobi \& Anekwe, 2017).

The concept of blended learning is an emerging concept that has varying conceptualizations ranging from infusion of technologies into the traditional face-to-face teaching and learning approaches to using multimedia facilities to sustainably stimulate learning environment and rouse students' interest to towards participating in classroom activities. It is in keeping with this view that Driscoll (2004) defined blended learning as the fusion of different teaching methods to attain learning objectives. Similarly, Kuo, Belland, Schroder and Walker (as cited in Ekhmimi, 2018) opined that blended learning is the combination of face-to-face teaching method with technologies in order to improve overall quality of instruction by strengthening students' involvement in classroom activities for the reason of accelerating their comprehension-pace for maximal understanding. The definitions above suggest that blended learning is the combination of multiple teaching methodologies, theories, principles, strategies, models and technologies to facilitate teaching and learning.

Technologies in education context may be defined as the application of organized knowledge, ICT tools and machineries to bolster the effectiveness of teaching and learning. Some of the technological facilities that instructors use to aid technology-based learning include live blogs 
and chat-rooms, message-boards, discussion platforms, virtual communities, social media tools (such as Facebook, Twitter, Youtube, etc.), synchronous video-conferencing and calls, instant messaging, webinar, applications, online forums and web-based tutorials using e-devices such as mobile phones, computers, projectors and other audio-visual gadgets that have data input and output interfaces for transmitting data through internet, High Definition (HD) and threedimensional (3D) live images (Okaz, 2015: Haruna \& Igbozuruike, 2019). Ali (2019) remarked that blended learning integrates some components of e-learning and online learning innovations to supplement the conventional face-to-face teaching method with the intension of improving the quality of teaching and learning so that instructional experiences will be very interesting, thrilling and comprehensive.

In fact, the face-to-face component of blended learning embraces both teacher and learnercentred approaches; however the e-leaning and online components of the learning innovation feature synchronous and asynchronous characteristics in practice. Ali (2019) remarked that when teaching and learning is conducted through online facilities such as webinar, and videoconferencing or any other forms of real-time discussions between learners and instructors, synchronous blended learning is said to have occurred. On the contrary, when instruction is conducted via email, text messages, social media platforms and forums where ideas and learning resources (including recorded videos, audios and digitalized e-books) are shared and downloaded for offline learning using computers, smartphones and other devices such as projectors, optical-disc and flash-drives, asynchronous blended learning is said to has taken place. Ezekoka (2015) remarked that e-learning component of blended learning permits students and their instructors to create e-platforms where professionals, cohort and focus groups, students and their lecturers can interact, share information, exchange scholarly ideas and challenge theories, ask questions and receive feedbacks on-the-go. Such a blend of technology with face-to-face method of instruction goes beyond making learning exciting and pleasurable, because it invokes the attention of learners and sustainably inspire their participation in classroom activities, with the result that their understanding and knowledge retention rate may increase to a level that will be difficult to attain with lecture method alone (Haruna \& Igbozuruike, 2019).

Conversely, Asarta and Schmidt (2017) observed that many researches on blended learning share common framework and contextual complexities that often inadvertently puncture their findings, some of which include the archetypical characteristics of those studies, and to a lesser degree; the too much reliance on circumstantial interpretation of the findings. For instance, Driscoll (2004) observed that slow learners learn better when the conventional method is used, while bright students comprehend faster when technology is combined with normal classroom instruction. Darrin (2018) pointed out that the challenge of determining suitable instructional designs for individual courses, and the question of digitizing curriculum contents and instructional resources in a manner that agrees with learners' diversities and self-directed learning, are among the greatest impediments facing blended learning.

Even so, instances of significant improvement on academic performance of students taught with blended learning abound (Al-Saleh, 2018; Turner,Young-Lowe \& Newton, 2018). This is because blended learning is so unique that it helps educators to combine different mediums to explain, highlight and dissect concepts and objects in order to heighten clarity, students' comprehension and learning outcomes (Noordink, 2012). This suggests that blended learning could be the panacea for addressing diverse learning difficulties experienced by many slow learners (Al-Qahtani \& Higgins, 2013). Turner et al. (2018) observed that blended learning creates learning opportunities that educators can seize to dissertate with students live, connect them to the right learning resources in the internet and coach them on strategies for searching 
for and accessing online and offline learning materials they may need to deepen their disciplinary knowledge and expand their intellectual horizon for improved academic and career successes.

Despite these advantages, observations suggest that Nigeria universities are still 'dragging their feet' over when and how to fuse blended learning into university system. Ezekoka (2015) reported that the implementation of blended learning in National Open University of Nigeria (NOUN) study centre in Owerri Imo State, was fraught with difficulties associated with lack of computer skills among the undergraduates, coupled with lack of ICTs facilities, including functional computers, projectors and reliable network to aid distance learning. Alshahrani (as cited in Ali, 2019) further reported that digital competences of instructors, and students' readiness to engage in sustainable independent scholarship posed significant challenge to blended learning; the scholar added that poor planning and implementation were largely responsible for implementation failures. This apparently highlights the importance of proper planning of blended learning prior to implementation phases.

Planning is the process of determining actions to take in advance and setting out programmes and implementation sequence to follow, making arrangements on how to mobilize scarce resources required to carry out the programmes designed to accelerate the attainment of set targets and objectives through plan implementation (Haruna \& Igbozuruike, 2019). Ukaigwe and Igbozuruike (2019:93) defined planning as a "conscious and deliberate effort of determining the future course of actions in advance, with a view to outlining programmes that will facilitate the attainment of desirable ends". The definitions above suggest that planning is a decision making process that involves examination of situation to determine what to do in the future, setting out goal-oriented programmes and breaking them down into tasks, scheduling the tasks in logical and economically efficient order of implementation towards the attainment of set objectives.

The first phase of integrating blended learning into university system is to develop blended learning guide that agrees with university's vision and mission statements that are understandable to school members, and in agreement with overall national goals on university education. This pre-planning managerial task is of fundamental precedence to planning exercise. At this initial stage, the school leadership will have to enlighten the members of the university communities and key external stakeholders on the significance and benefits of blended learning to students, lecturers and university system for overall national developments. This awareness creation is important because it will take school-system-wide cohesion and external supports to plan, implement and mainstream blended learning into conventional university schooling system (Jiang, 2012).

Jiang (2012) further observed that such a school-based planning process will require the vicechancellor and other principal officers to assemble university's stakeholders, which ought to include educational planners, administrators, curriculum developers and digital content designers, lecturers, digital technologist, web-developers and instructional managers, etechnicians, knowledgeable architects, students' representatives and other relevant experts to deliberate on the modalities for blending technologies with face-to-face teaching method. The assembly of planners should be led by an experienced educational manager, who is also knowledgeable in digital education and administration so that he/she can be able to set up and interface with committees made up of experts to handle different aspects of planning including fact finding tasks. Agabi (1999) suggested that the primary purpose of such committees is to serve as consultative bodies to the planners in areas of providing useful data and information to guide discussions and deliberations that ought to lead to concurrencies and decisions- 
making. This is agreement with Madumere (1997), who noted that gathering of data that will aid determination of unit costs, operational costs and maintenance cost will be necessary for determining total annual cost requirement for effective plan implementation. In addition to recurrent cost, other cost that have to be factored in include cost of resources that will be expended on programme monitoring, system maintenance, technical supports services, follow up exercise, performance evaluation activities and feedbacks (Ukaigwe \& Igbozuruike, 2019).

Jiang (2012) remarked that planners will proceed by outlining the strategies for generating funds that will be used to acquire standardized telecommunication infrastructures, instructional facilities and equipment to ensure hitch-free plan implementation and sustainability. The facilities have to meet functional requirements for teaching specific courses in blended learning environment; hence the planners have to ensure that staff and facilities meet quality and quantity requirements, technical standards and students' diversities. Haruna and Igbozuruike (2019) further noted that the services of engineers and architects is necessary during building designs, so that professional attention can be given to the size and population of students in terms of type, space and installations, in such a way that improves not only the quality of learning environment in terms of aesthetic and brilliance, but also safety and security of both staff and students. Such a coherent planning will require the absolute support of institutional leadership from the onset in areas of timely release of budgeted funds to aid procurement and installation of infrastructures such as electricity, equipment and ICT facilities such as internet, satellite dish, Wi-Fi, laptops and desktop computers, projectors, televisions, electronic boards, books and other learning resources (Haruna \& Igbozuruike, 2019).

Mezieobi and Anekwe, (2017) opined that effective integration of blended learning will require an individual university to determine manpower needs in terms of staff quality and strengths, competence and training needs of lecturers, technicians and support staff so that preparations can be made to address issues bothering on continuous professional development (CPD) of staff, in order that both old and new staff can acquire ITCs skills, and new pedagogical skills necessary for effective blending of learning modes. Haruna and Igbozuruike (2019) observed that planners will have to liaise with experts in website development, software engineering and digital designing in areas of working out modalities for curriculum content digitization, so that students will not only be able to browse online resources uploaded by their instructors, but will also be able to download them using their unique login usernames and passwords. The scholars further suggested that plan implementation control managers such as Deans of Faculties and Heads of Departments (HOD) may appoint persons to assist them in monitoring the plan implementation in their areas of jurisdiction. Top managers may schedule bi-monthly or weekly meetings with middle level managers to receive and deliberate on progress reports and feedbacks on the acceptance, effectiveness and efficiency of blended learning.

Ekhmimi (2018) remarked that integration of blended learning into school system will suffer set-backs if there is no comprehensive and synchronous students' database with which the university employees can use to identify and contact students and their parents when necessary, record continuous assessments scores, and publish results in designated school website. This requires reliable technological infrastructures such as an excellent communication network, broadband services, computer hardwires and peripheries, applications and digital platforms that gives individual students access to wide range of learning resources. The online environment have to be designed and managed in such a way that protects students' and instructors' privacy, dignity and right to participate, contribute and discussions issues with decorum. 


\section{Statement of the Problem}

The traditional face-to-face lecture method of teaching in universities has been criticized for not producing the desired behavioural change on students, especially in the area of practical skill development. Lecture method alone does not provide opportunities for productive interaction between learners and instructors. The method is now being designated as being passive because it offers restricted opportunities for learners to inquire into information delivered to them. Apart from its contrariety with activity-based learning approaches considered to be more effective, the lecture method rarely affords instructors the essential reflective space they require to engage self and the learners in higher-order thinking and cognition during instruction. This may explain why many university graduates find it difficult to demonstrate practical skills commensurate with their training, with the result that many do not have useful and marketable skills that command economic value in the labour market. Hence, the face-to-face traditional method of teaching alone may no longer be appropriate for developing skilful individuals who can use the learnt skills to contribute to national development. Consequently, many universities are now making attempts towards integrating technologies into face-to-face teaching method, but the efforts made in this regard have largely produced futile results due to certain causative factors such as unreliable communication network, lack of power supply and e-learning facilities, lack of digital skills among instructors and students, most of which were traced to lack of effective planning. Hence, the researchers investigated the ways of integrating blended learning in university system using planning as a tool.

\section{Aim and Objectives}

The aim of this study was to investigate the ways of integrating blended learning into the traditions of universities, using planning as a tool. Specifically, the study intended to:

1. find out the ways of enhancing the integration of blended learning in the university system.

2. ascertain the ways planning facilitates the integration of blended learning in university system.

\section{Research Questions}

1. What are the ways of enhancing the integration of blended learning in university system?

2. In what ways do planning facilitate the integration of blended learning in university system?

\section{Hypothesis}

- There is no significant difference between the mean ratings of male and female respondents on the ways of enhancing the integration of blended learning in university system?

- There is no significant difference between the mean ratings of male and female respondents on the ways planning facilitates the integration of blended learning in university system.

\section{METHODOLOGY}

The study adopted descriptive survey design. The population of this study consisted of the 4,377 teaching staff in the three (3) public universities in Rivers State, comprising 2,348 male and 2,029 female teaching staff. The universities are the University of Port Harcourt, Rivers State University and Ignatius Ajuru University of Education. The sample of this study was 590 elements, comprising 327 male and 263 female teaching staff of the three universities, who were drawn using random sampling technique. Instrument of data collection was a 
questionnaire titled, 'Planning and Integration of Technologies for Effective Implementation of Blended Learning in Universities Questionnaire' (PITEIBLUQ).The instrument was a validated questionnaire scaled in four point Likert form of Strongly Agree (SA), Agree (A), Disagree (D) and Strongly Disagree (SD). The reliability test yielded a reliability index of 0.84, using testretest and Pearson Product Moment Correlation techniques. The instrument consisted of two sections; Section A was used to elicit demographic data of the respondents, while section B included 10 questionnaire items structured to obtain responses from the respondents. The data generated were analysed using mean, and mean-set to answer research questions. The decision to accept or reject any item was determined by this calculation $=\underline{4+3+2+1}=\underline{10 / 4}=$ 2.50. Hence, items that scored $\mathrm{x} \geq 2.50$ were accepted whereas those below it were rejected. Ztest was used to test the two hypotheses at 0.05 alpha.

\section{Research Questions One}

\section{RESULTS}

Table 1: Mean ratings of male and female teaching staff on the ways of enhancing the integration of blended learning in university system

\section{Description of Items}

\begin{tabular}{ccc} 
Means of & Mean & Remarks \\
Teaching Staff & -sets & \\
Male Female & & \\
\hline
\end{tabular}

\begin{tabular}{llll}
3.10 & 3.12 & 3.11 & Agreed \\
3.08 & 3.21 & 3.15 & Agreed \\
3.20 & 3.12 & 3.16 & Agreed \\
3.09 & 3.23 & 3.16 & Agreed \\
& & & Agreed \\
2.79 & 3.14 & 3.00 & \\
$\mathbf{3 . 0 5}$ & $\mathbf{3 . 1 6}$ & $\mathbf{3 . 1 1}$ & \\
\hline & & &
\end{tabular}

1. Aligning university vision with the aspirations of full integration of blended learning into university system.

2. Provision of required communication networking infrastructures.

3. Modifying curriculum designs to become deliverable through blended learning mode.

4. Preparing instructors and students to acquire digital skills required to adapt to blended learning environment.

5. Developing operative data-based of staff and students to enhance functionality of online virtual communities. Grand Mean

Data in table 1 shows that all the items were agreed, with the result that high grand mean scores of 3.05 and 3.16 for male and female respondents were obtained respectively. The high grand mean-set of 3.11 is higher than 2.50 criterion mean score, and thus implies that the above itemized statements are the ways of enhancing the integration of blended learning in university system.

$\mathrm{H}_{\mathrm{o} 1}$

Table 2: Z-test of the difference between the mean ratings of male and female teaching staff on the ways of enhancing the integration of blended learning in university system

\begin{tabular}{cccccccccc} 
S/No & Teaching Staff & N & Mean & SD & Df & $\begin{array}{c}\text { z- } \\
\text { cal. }\end{array}$ & z-crit. & $\begin{array}{c}\text { Significant } \\
\text { Level }\end{array}$ & Remark \\
\hline 1. & Male & 327 & 3.05 & 0.69 & & & & & \\
& & & & & 588 & 1.76 & \pm 1.96 & 0.05 & $\begin{array}{c}\text { Not Significant } \\
\text { (Hoccepted) }\end{array}$ \\
2. & Female & 263 & 3.16 & 0.80 & & & & & \\
\hline
\end{tabular}

Table 2 shows that at 588 degrees of freedom and 0.05 significance level, the z-calculated value of 1.76 is lower than z-critical value of \pm 1.96 . Hence, no significant difference exists between 
the mean scores of male and female teaching staff on the ways of enhancing the integration of blended learning in university system.

\section{Research Question Two}

Table 3: Mean ratings of male and female teaching staff on the ways planning facilitates the integration of blended learning in university system

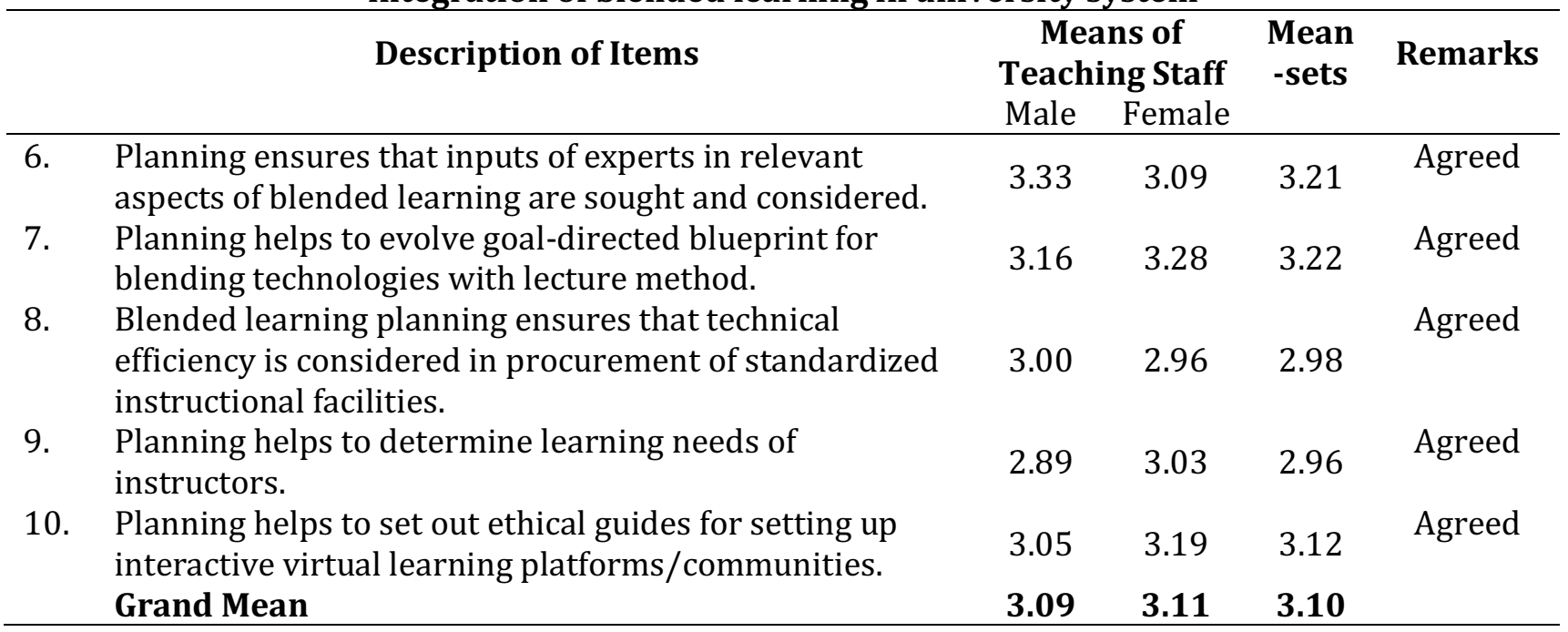

Data in table 3 shows that all the items were agreed, with the result that high grand mean scores of 3.09 and 3.11 for male and female respondents were obtained respectively. The high grand mean-set of 3.10 is higher than 2.50 criterion mean score; hence the above itemized statements are the ways planning facilitates the integration of blended learning in university system.

$\mathrm{H}_{\mathbf{0} 2}$ :

Table 4: Z-test of the difference between the mean ratings of male and female teaching staff on the way planning facilitates the integration of blended learning in university system.

\begin{tabular}{cccccccccc}
\hline S/No & $\begin{array}{c}\text { Teaching } \\
\text { Staff }\end{array}$ & N & Mean & SD & Df & $\begin{array}{c}\text { z- } \\
\text { cal. }\end{array}$ & $\begin{array}{c}\text { z-crit. } \\
\text { Significant } \\
\text { Level }\end{array}$ & Remark \\
\hline 1. & Male & 327 & 3.09 & 0.87 & & & & & \\
& & & & & 588 & 0.28 & \pm 1.96 & 0.05 & $\begin{array}{c}\text { Not Significant } \\
\text { (Hoccepted) }\end{array}$ \\
2. & Female & 263 & 3.11 & 0.84 & & & & & \\
\hline
\end{tabular}

Table 4 reveals that at 588 degrees of freedom and 0.05 level of significance, the z-calculated value of 0.28 is lower than $z$-critical value of \pm 1.96 . Hence, no significant difference exists between the mean scores of male and female teaching staff on the ways planning facilitates the integration of blended learning in the university system.

\section{FINDINGS, DISCUSSION AND IMPLICATION}

The analysis of data in table 1 showed that aligning university's vision with the aspirations of full integration of blended learning into university system, provision of required communication networking infrastructures and modifying curriculum designs to become deliverable through blended learning mode are key ways of integrating blended learning into the university system according to the findings. These findings agree with Jiang (2012) who reported that sharing the school goals on the integration of e-learning with major stakeholders such as instructors, students, parents and others played key role in assisting the school leadership and government to draw the blueprint for integration of technologies in 
instructional delivery process, with the result that success was recorded and goals attained. The scholar further associated the successes attained to supports it received from schools leadership, and synergy between planners, teachers and other stakeholders who were part of the planning and implementation process. Vo, Zhu \& Diep (2017) observed that blended learning requires adequate provision of communication infrastructures and equipment in line with standards set out in the plan. This is because non-provision of relevant facilities such power supply, computers and efficient network system such as internet, LAN and Wi-Fi will truncate plan implementation (Ekekoka, 2015: Ali, 2019). This study further revealed that one of the ways of integrating blended learning include helping school staff and students to acquire digital skills with which to function effectively in blended learning environment. Others include developing operative data-base of staff and students to enhance functionality of online virtual communities. It is therefore of no wonder that no significant difference existed between the mean scores of male and female respondents on the ways of enhancing the integration of blended learning in university system. Hence, these findings agree with Haruna and Igbozuruike (2019) who observed that planning helps in harmonising arrangements for integration of e-learning in schools. This was because planning ensures that funds required for training lecturers on how to manipulate and combine multimedia devices to improve face-toface teaching and learning are determined and set aside through budgeting (Madumere, 1997). The findings is consistent with Ali (2019) who remarked that training helps to equip instructors with digital skills required for reconstructing instructional designs to spice-up learning environment with technologies, motivate students with illustrations to retain their attention, and improve their learning experiences by involving them in learning activities to boost their understanding.

The finding on the ways planning facilitates the integration of blended learning in university system indicated that planning ensures that inputs of experts in relevant aspects of blended learning are sought and considered. The findings further showed that planning helps to evolve goal-directed blueprint for blending technologies with lecture method, and also ensures that technical efficiency is considered in procurement of standardized digital instructional facilities. These findings agree with Hinton and Cooner (2009), who remarked that planning is a key tool for mainstreaming electronic and online learning technologies (blended learning) into face-toface teaching method. The scholars affirmed that planning helps institutions to restructure educational specifications and objectives in order to form the basis for long term improvements strategy for sustainable integration of blended learning into university system.

Furthermore, Ezekoka (2015) reported that planning and implementation of blended learning not only enables university students to learn while on-the-go, but also helps them to balance their work and academics. It is therefore of no wonder that Ja'ashanas (as cited in Ali, 2019), reported that blended learning was well-planned that students were not just satisfied with it, because they showed positive attitude towards it. Similarly, Saritepeci and Cakir (2015) reported that adequate planning and implementation of blended learning proved to be exceedingly better than the conventional classroom instruction, with the result that students' involvement in classroom activities improved so significantly that students' academic performances were remarkably enhanced.

\section{CONCLUSION}

Having established the ways through which blended learning can be integrated into the traditional teaching methods in university system, in addition to the ways planning enhances the integration of technologies in instruction delivery, this study therefore concludes that planning plays key role in enhancing the integration of blended learning into the conventional teaching methods for improving students learning outcomes. 


\section{RECOMMENDATIONS}

Based on the findings, the following recommendations were made;

1. University managers should consider seriously, the advantages of blended learning in the school system, with a view to using planning to foster the integration of the learning innovation into the traditional face-to-face teaching and learning approach for improving students learning experiences and achievements.

2. School managers should prepare instructors to become knowledgeable in utilization of ICTs facilities and devices. They should also adjust the curriculum implementation modalities to ensure effective integration of blended learning into the university system.

\section{References}

Agabi, O. G. (1999). Introducing educational planning. Port Harcourt: International Centre for Educational Services. Ali, A. (2019).Blended learning in Saudi Arabia - A review. Global Journal of Education and Training, 2(6) 1-7 Al-Qahtani, A. A. Y., \& Higgins, S. E. (2013). Effects of traditional, blended and e-learning on students' achievement in higher education. Journal of Computer Assisted Learning, 29(3), 220-234.

Al-Saleh, R.S.S. (2018). EFL teacher's attitudes towards blended learning in Tabuk, Saudi Arabia. International Journal of Information Research and Review, 5(1), 5065-5071.

Anusiem, A. U. (2006). Processes of human learning. Owerri: Divine Mercy Publishers

Asarta, C. J. \& Schmidt, J. R. (2017). Comparing student performance in blended and traditional courses: Does prior academic achievement matter? The Internet and Higher Education, 32, 29-38.

https://doi.org/10.1016/j.iheduc.2016.08.002

Dele, H. S. (2008). Learning theories: An educational perspective. Pearson, London.

Driscoll, M. P. (2004). Psychology of learning for instruction (3rd ed). New Jersey: Allyn \& Bacon.

Ekhmimi, T.A. (2018). Blended learning among adults in Saudi Arabia (Unpublished master's thesis). Eastern Washington University, Cheney, Washington

Ezekoka, G. K. (2015).Blended learning in National Open University of Nigeria (Noun) - Prospects and Constraints. International Journal of Innovation and Research in Educational Sciences, 2 (6) 457-461

Haruna, U. \& Igbozuruike, I. U (2019).Integration of e-learning in secondary education and the imperatives of planning for sustainable improvement in students' achievement in Port-Harcourt Metropolis. Paper presented at the 21st annual national conference of Nationwide Association for the Advancement of Knowledge (NAFAK). Held at National Open University of Nigeria (NOUN), Trans Ekulu Enugu State.

Jiang, M. (2012).Research Highlights Improved Teaching and Learning Through the 1:1 eLearning Initiative in Shanghai. USA: Intel Corporation

Madumere, S.C. (1997). Educational planning and manpower development. Lagos: Samuel Printing Press.

Mezieobi, S. A. \& Anekwe, J. U. (2017).Blending learning in university education: affordances and drawbacks for digital natives and digital immigrants in developing nations. European Journal of Research and Reflection in Educational Sciences, 5(2) 68-84

Noordink, M. (2010). Different ways of teaching different pedagogical approaches. Retreived from online blog http://marlijnenoordink.blogspot.com.

Obasi, V. A. Obih, S. A. \& Udosen, A. (2016). Factors affecting learning. In T.N. Kanno, V. A. Obasi, \& S. A. Obih, (Eds). Contemporary issues in curriculum implementation \& methods. Owerri: Hysab Prints \& Pubnlishers

Okaz, A. (2015). Integrating Blended Learning in Higher Education. Social and Behavioral Sciences 186, 600 - 603

Sarıtepeci, M. \& Cakir, H. (2015). The effect of blended learning environments on student motivation and student engagement: A study on social studies course. Education and Science, 40(170), 203-216.

Turner, J., Young-Lowe, W. \& Newton, J. (2018). Teachers' perceptions of the use of blended learning for instructional delivery and student production in K-12 Classrooms. International Journal of Learning and Development, 8 (2) 18-26 
Ukaigwe, P. C. \& Igbozuruike, I. U. (2019). Planning: A tool for administration of teachers' competence development programmes for improved service delivery in secondary schools in Rivers State, Nigeria. Advances in Social Sciences Research Journal, 6(1) 91-100.

Vo, H. M., Zhu, C., \& Diep, N. A. (2017). The effect of blended learning on student performance at course-level in higher education: A meta-analysis. Studies in Educational Evaluation, 53, 17-28.

https://doi.org/10.1016/j.stueduc.2017.01.002 